\title{
The introduction of Arcobacter spp. in poultry slaughterhouses
}

\author{
Hoa T.K. Ho ${ }^{\text {a,b }}$, Len J.A. Lipman ${ }^{\text {a,* }}$, Wim Gaastra ${ }^{\text {a }}$ \\ ${ }^{\text {a }}$ Faculty of Veterinary Medicine, Utrecht University, The Netherlands \\ ${ }^{\mathrm{b}}$ Faculty of Animal Husbandry and Veterinary Medicine, Nong Lam University, Ho Chi Minh City, Vietnam
}

Received 3 October 2007; received in revised form 30 January 2008; accepted 14 February 2008

\begin{abstract}
Despite the presence high levels of Arcobacter spp. on chicken carcasses, the source of arcobacter contamination in slaughterhouses still remains unclear. It has been hypothesised in the literature that Arcobacter species that contaminate carcasses originate in in-plant slaughterhouses and/or supply water. The present study aimed to determine the source of Arcobacter contamination in two poultry slaughterhouses in The Netherlands. Carcasses and intestinal tracts from 3 hen flocks and 2 broiler flocks were collected. Water draining off carcasses during processing in 2 slaughterhouses and supply water in one slaughterhouse were also taken. For one flock, cloacal swabs and faecal samples were taken on the farm before slaughtering. ERIC-PCR was applied to study the genetic diversity and relationship among the isolates. No Arcobacter spp. were found in the supply water but on almost all of the sampled carcasses and in carcass-draining-off water arcobacters were identified. Arcobacter spp. were detected in the gut systems of chickens, ranging from $20 \%$ to $85 \%$ in hens and $3.3 \%$ and $51 \%$ in broilers. Similar ERIC-PCR genotypes were detected in gut contents as well as on carcasses from the same flock. The present study demonstrated that Arcobacter spp. can be detected in chicken intestines at slaughter and could be brought in this way into slaughterhouses where the bacteria contaminate carcasses during processing. (C) 2008 Elsevier B.V. All rights reserved.
\end{abstract}

\section{Introduction}

The genus Arcobacter was proposed in 1991 and belongs to the family Campylobacteraceae (Vandamme and De Ley, 1991; Vandamme et al., 1991). Like Campylobacter, Arcobacter species have been indicated as foodborne microorganisms since they have been detected in food of animal origin, especially in products from chicken all over the world (de Boer et al., 1996; Kabeya et al., 2004; Rivas et al., 2004; Son et al., 2006). The bacteria are found on almost all sampled broiler carcasses with a significantly higher recovery rate than Campylobacter spp. for the same samples (Houf et al., 2002b). Up to several thousand bacteria were present per gram of neck skin prior to evisceration. Arcobacter spp. are recovered from carcasses at

\footnotetext{
* Corresponding author. Division of Public Health and Food Safety, Institute for Risk Assessment Sciences, Utrecht University, Yalelaan 2, 3508TD Utrecht, The Netherlands. Tel.: 31302535342.

E-mail address: Lipman@uu.nl (L.J.A. Lipman).
}

different processing stages (e.g. pre- and post-scald, pre- and post-evisceration and pre- and post-chill) (Houf et al., 2002b; Son et al., 2007) as well as along the slaughterhouse processing line, equipment and processing water (Houf et al., 2002b; Houf et al., 2003; Gude et al., 2005). The organisms are hardly isolated from the gut contents of birds belonging to the same flock where arcobacter-positive carcasses come from (Atabay and Corry, 1997; Houf et al., 2002b). It has been hypothesised that Arcobacter spp. are probably not normal inhabitants of chicken intestines (Eifert et al., 2003; Gude et al., 2005; Gonzalez et al., 2007). The source of arcobacter contamination on carcasses would be the slaughterhouse environment and/or water used during processing (Atabay and Corry, 1997; Gude et al., 2005; Van Driessche and Houf, 2007).

The aim of this study was to determine the source(s) of introduction of Arcobacter species in chicken slaughterhouses by examining the presence of Arcobacter spp. on chicken carcasses, in the content of different parts of the chicken intestine and in the water supply of two poultry slaughterhouses in The Netherlands. 


\section{Materials and methods}

\subsection{Sampling}

Carcasses and intestinal tracts of chickens were obtained from two slaughterhouses in The Netherlands (with a capacity of 10,000-12,000 birds per hour). Both slaughterhouses are operated under the EU hygiene regulations 852, 853 and 854/2004. At slaughterhouse 1, three flocks of laying hens were sampled (on different days). From flock 1, twenty pre-chilling carcasses and 40 intestinal tracts were randomly taken. Five days prior to slaughtering of this flock, 50 cloacal swabs and 6 faeces pools (each containing 5-6 different faecal droppings) were collected randomly on the farm. Thirty pre-evisceration carcasses were collected from flock 2 and 40 intestinal tracts were collected from flock 3. At slaughterhouse 2, samples were taken randomly from 2 different broiler flocks on 2 different days. Thirty pre-evisceration carcasses were collected from one flock. Twenty pre-evisceration carcasses and 100 intestinal tracts were collected from the other. In addition, approximately $100 \mathrm{ml}$ of water draining off from hanging broiler carcasses at different processing stages was collected: (1) from carcasses immediately after leaving the scalding tank (operated at $52{ }^{\circ} \mathrm{C} / 3 \mathrm{~min}$ ), (2) from carcasses after defeathering and washing and (3) after the last wash before entering the chilling room. Tap water used as processing water in the slaughterhouse was also sampled $(500 \mathrm{ml})$.

\subsection{Sample processing}

Cloacal swabs taken on the farm were immediately placed in $10 \mathrm{ml}$ Arcobacter broth (Oxoid, CM965) supplemented with CAT supplement (Cefoperazone, Teicoplanin, Amphotericin B, Oxoid, SR174). Other samples, collected on the farm or in slaughterhouses, were transported on ice to the laboratory and were processed within a few hours. Arcobacter broth without CAT supplement was used for processing samples (for homogenisation, rinsing or wiping). The processed samples were inoculated in Arcobacter broth supplemented with CAT, (from now on referred to as enrichment medium). Twenty grams of each faecal pool was homogenised (by vortex) in $40 \mathrm{ml}$ Arcobacter broth and $1 \mathrm{ml}$ of the suspension was added to $9 \mathrm{ml}$ enrichment broth. Post-evisceration carcasses were rinsed with $100 \mathrm{ml}$ Arcobacter broth in sterile plastic bags and preevisceration carcasses were wiped with a sterile cotton compress wetted in $100 \mathrm{ml}$ Arcobacter broth. One $\mathrm{ml}$ of the samples obtained by rinsing or wiping of carcasses was then inoculated in $9 \mathrm{ml}$ enrichment medium. The sampling area of the intestinal tracts was flushed with $75 \%$ ethanol and scissors sterilised in a burning flame were used to open the guts. The content of 10-cm duodenum, 10-cm ileum or 5-cm caeca was collected using a sterile scalpel, mixed with sterile cotton swabs and placed in $10 \mathrm{ml}$ enrichment broth. One $\mathrm{ml}$ of carcass-draining-off water was inoculated in $9 \mathrm{ml}$ enrichment medium. Fifty $\mathrm{ml}$ of tap water was centrifuged for $20 \mathrm{~min}$ at $4000 \times g$ and $15^{\circ} \mathrm{C}$. Forty nine $\mathrm{ml}$ of the supernatant was gently removed and $9 \mathrm{ml}$ enrichment medium was added and mixed with the remaining 1-ml sample.
All enrichment samples were incubated for $48 \mathrm{~h}$ at $30^{\circ} \mathrm{C}$ under microaerophilic conditions (generated by BD CampyPak ${ }^{\mathrm{TM}}$, Becton, Dickinson and Company).

\subsection{Detection of Arcobacter spp.}

The presence of Arcobacter spp. was investigated both by PCR and isolation of the bacteria. After 48-hour incubation, DNA from each enrichment culture was extracted by the boiled lysate method. The presence of Arcobacter DNA was examined by a genus-specific PCR reaction (primer 219 f: GAG ATT AGC CTG TAT TGT ATC, primer 1427r: TAG CAT CCC CGC TTC GAA TGA) (Harmon and Wesley, 1996). PCR-positive samples were retested with a multiplex PCR (m-PCR) for species specification (using primers ARCO: CGT ATT CAC CGT AGC ATA GC; BUTZ: CCT GGA CTT GAC ATA GTA AGA ATG A; SKIR: GGC GAT TTA CTG GAA CAC A; CRY 1: TGC TGG AGC GGA TAG AAG TA; CRY 2: AAC AAC CTA CGT CCT TCG AC) (Houf et al., 2000). Samples that were negative in the arcobacter-specific PCR were tested by PCR with eubacterial primers (27 f: AGA GTT TGA TCM TGG CTC AG; 519r: GWA TTA CCG CGG CKG CTG; $\mathrm{K}=\mathrm{G}, \mathrm{T} ; \mathrm{M}=\mathrm{A}, \mathrm{C} ; \mathrm{W}=\mathrm{A}, \mathrm{T}$ ) for the possible presence of inhibitors. DNA from A. butzleri LMG 6620, A. cryaerophilus LMG 7537 and A. skirrowii LMG 6621 was used as positive controls.

For isolation of bacteria, $50 \mu \mathrm{l}$ of each enrichment sample was dropped on a cellulose-nitrate membrane filter $(0.65 \mu \mathrm{m})$ (Sartorius, The Netherlands) which was placed on blood agar plates (Brain Heart Infusion Agar, Oxoid, plus 5\% horse blood) supplemented with CAT (Cefoperazone, Teicoplanin, Amphotericin B, Oxoid). After 1-hour incubation at $30^{\circ} \mathrm{C}$ in air, the filters were removed, the filtrates were evenly distributed over the agar surface with a sterile spreader, and the plates were incubated for $48 \mathrm{~h}$ at $30^{\circ} \mathrm{C}$ under microaerophilic conditions. Plates with no growth were incubated for two more days. Three to five colonies from each plate suspected to be Arcobacter spp. (small, nonpigmented or grey on blood agar plate) were transferred to blood agar plates without antimicrobial supplement and incubated for $48 \mathrm{~h}$ at $30^{\circ} \mathrm{C}$ under microaerophilic conditions. Isolates were purified by passing onto blood agar plates at least 3 times. The isolates were confirmed to be Arcobacter spp. by the m-PCR (Houf et al., 2000).

\subsection{Enterobacterial repetitive intergenic consensus (ERIC)-PCR}

To investigate the genotypic diversity and the genetic relationship among the isolates, ERIC-PCR was performed on the isolated Arcobacter strains (primer 1: ATG TAA GCT CCT GGG GAT TCA C and primer 2: AAG TAA GTG ACT GGG GTG AGC G) (Houf et al., 2002a). DNA of the isolates was obtained by the boiled lysate method and $3 \mu 1$ was used in $25 \mu 1$ total reaction volume.

\subsection{Survival of Arcobacter isolates under scalding conditions}

Five Arcobacter isolates, two A. butzleri, two A. cryaerophilus and one A. skirrowii, were randomly chosen for testing their 
Table 1

Presence of Arcobacter spp. in samples as determined by PCR and by isolation

\begin{tabular}{|c|c|c|}
\hline & $\begin{array}{l}\text { Numbers of positive } \\
\text { samples/ total }\end{array}$ & $\begin{array}{l}\text { Numbers of positive } \\
\text { samples by PCR/ } \\
\text { by isolation }\end{array}$ \\
\hline \multicolumn{3}{|c|}{ Slaughterhouse 1 - Flock 1 (hens) } \\
\hline Cloacal swabs ${ }^{\mathrm{a}}$ & $0 / 50$ & $0 / 0$ \\
\hline Faecal droppings ${ }^{a}$ & $2 / 6$ & $1 / 2$ \\
\hline Carcasses & $20 / 20(100 \%)$ & $20 / 20$ \\
\hline Intestinal tracts & $34 / 40(85 \%)$ & $34 / 33$ \\
\hline Duodenum & & $9 / 8$ \\
\hline Ileum & & $6 / 6$ \\
\hline Caeca & & $5 / 5$ \\
\hline Duodenum + ileum & & $2 / 2$ \\
\hline Duodenum + caecum & & $1 / 1$ \\
\hline Ileum + caecum & & $7 / 7$ \\
\hline 3 positions & & $4 / 4$ \\
\hline \multicolumn{3}{|c|}{ Slaughterhouse 1 - Flock 2 (hens) } \\
\hline Carcasses & $30 / 30(100 \%)$ & $30 / 24$ \\
\hline Intestinal tracts & $6 / 30(20 \%)$ & $6 / 4$ \\
\hline Ileum & & $3 / 3$ \\
\hline Caeca & & $1 / 1$ \\
\hline Ileum + caecum & & $2 / 0$ \\
\hline \multicolumn{3}{|c|}{ Slaughterhouse 1 - Flock 3 (hens) } \\
\hline Intestinal tracts & $13 / 40(43.3 \%)^{\mathrm{b}}$ & $5 / 10^{\mathrm{b}}$ \\
\hline Ileum & & $3 / 8$ \\
\hline Caeca & & $2 / 0$ \\
\hline Ileum + caecum & & $0 / 2$ \\
\hline \multicolumn{3}{|c|}{ Slaughterhouse 2- Flock 4 (broilers) } \\
\hline Carcasses & $30 / 30(100 \%)$ & $30 / 28$ \\
\hline Intestinal tracts & $1 / 30(3.3 \%)$ & $1 / 1$ \\
\hline Ileum & & $1 / 1$ \\
\hline Caeca & & 0 \\
\hline Ileum + caecum & & 0 \\
\hline $\begin{array}{l}\text { Drippings } 1 \\
\text { (post-scalding) }\end{array}$ & $1 / 2$ & $1 / 0$ \\
\hline $\begin{array}{l}\text { Drippings } 2 \\
\text { (post-defeathering) }\end{array}$ & $2 / 2$ & $2 / 2$ \\
\hline Drippings 3 (pre-chill) & $2 / 2$ & $2 / 0$ \\
\hline Tap water & $0 / 2$ & $0 / 0$ \\
\hline \multicolumn{3}{|c|}{ Slaughterhouse $2-$ Flock 5 (broilers) $^{\mathrm{c}}$} \\
\hline Carcasses & $15 / 20(75 \%)$ & 15 \\
\hline Intestinal tracts & $51 / 100(51 \%)$ & 51 \\
\hline Ileum & & 26 \\
\hline Caeca & & 8 \\
\hline Ileum + caecum & & 17 \\
\hline $\begin{array}{l}\text { Drippings } 1 \\
\text { (post-scalding) }\end{array}$ & $0 / 1$ & 0 \\
\hline $\begin{array}{l}\text { Drippings } 2 \\
\text { (post-defeathering) }\end{array}$ & $1 / 1$ & 1 \\
\hline $\begin{array}{l}\text { Drippings } 3 \\
\text { (pre-chilling) }\end{array}$ & $2 / 2$ & 2 \\
\hline Tap water & $0 / 2$ & 0 \\
\hline
\end{tabular}

${ }^{a}$ Samples were taken on the farm before slaughtering.

${ }^{\mathrm{b}}$ For this flock, 5 tracts were PCR-positive, but arcobacters were isolated from 10 tracts including 2 PCR-positive tracts.

${ }^{c}$ For this flock, the investigation was done by PCR only.

survival after $3 \mathrm{~min}$ in water at 52 and $58^{\circ} \mathrm{C}$. One $\mathrm{ml}$ of a 10 -fold, 100 -fold or 1000-fold dilution of an overnight broth culture of each strain was inoculated in $9 \mathrm{ml}$ sterile water that had been placed in a water bath of 52 or $58^{\circ} \mathrm{C}$ at least $1 \mathrm{~h}$ prior to the assay. After 3-minute incubation, $100 \mu \mathrm{l}$ from each sample was transferred onto blood agar plates and another $100 \mu \mathrm{l}$ was added into $900 \mu \mathrm{BHI}$ broth (Brain Heart Infusion, Oxoid) at room tem- perature, for serial dilution. One hundred $\mu 1$ of each dilution was then spread onto blood agar plates. The plates were incubated for 2 days at $30{ }^{\circ} \mathrm{C}$ under microaerophilic conditions and colonies were counted.

\section{Results}

\subsection{Presence of Arcobacter spp. in samples}

The presence of Arcobacter spp. in samples detected both by PCR and isolation is presented in Tables 1 and 2. In general, the PCR technique yielded a higher prevalence of Arcobacter spp. than the isolation method. The isolation of Arcobacter species from some PCR-positive samples was unsuccessful due to overgrowth by other enteric bacteria or fungi. Arcobacters were also isolated from a few PCR-negative samples. Therefore, the number of positive samples was calculated by combination of the results from both PCR and isolation.

Almost all sampled carcasses were Arcobacter-positive. From flock 1 (hens), 1 faecal sample (out of 6) taken on the farm was PCR-positive and A. skirrowii was isolated. In addition, A. cryaerophilus was isolated from 1 PCR-negative sample. None of the 50 cloacal swab samples taken on the farm were Arcobacter-positive either by PCR or isolation. However, Arcobacters were detected in the content of 34 out of 40 intestinal tracts (85\%) taken from the same flock. The majority of the isolates from these samples were identified as A. butzleri. Both A. butzleri

Table 2

Identification of Arcobacter species in enrichment samples by m-PCR and by isolation

\begin{tabular}{|c|c|c|c|c|c|}
\hline & Specie & & & & \\
\hline & Butz & Cry & Skir & $\begin{array}{l}\text { Butz+ } \\
\text { cry }\end{array}$ & $\begin{array}{l}\text { Butz+ } \\
\text { skir }\end{array}$ \\
\hline Slaughterhouse 1 - Flock 1 (hens) & & & & & \\
\hline Faecal droppings & & $0 / 1$ & $1 / 1$ & & \\
\hline Carcasses & $9 / 8$ & $0 / 5$ & & $11 / 7$ & \\
\hline Intestinal samples ${ }^{\mathrm{c}}$ & $48 / 45$ & $2 / 2$ & $2 / 1$ & $0 / 3$ & \\
\hline Slaughterhouse 1 - Flock 2 (hens) & & & & & \\
\hline Carcasses & $11 / 2$ & $1 / 16$ & & $18 / 6$ & \\
\hline Intestinal samples & $1 / 0$ & $2 / 4$ & & $5 / 0$ & \\
\hline Slaughterhouse 1 - Flock 3 (hens) & & & & & \\
\hline Intestinal samples ${ }^{\mathrm{c}}$ & $4 / 11$ & $0 / 1$ & & $1 / 0$ & \\
\hline Slaughterhouse 2 - Flock 4 (broile & & & & & \\
\hline Carcasses & $23 / 21$ & $0 / 2$ & & $0 / 5$ & $7 / 0$ \\
\hline Intestinal samples ${ }^{\mathrm{c}}$ & $1 / 1$ & & & & \\
\hline Drippings 1 (post-scalding) & & & & & $1 / 0$ \\
\hline Drippings 2 (post-defeathering) & & $0 / 2$ & & $2 / 0$ & \\
\hline Drippings 3 (pre-chilling) & & & & $2 / 0$ & \\
\hline Slaughterhouse 2 - Flock 5 (broile & & & & & \\
\hline Carcasses & 15 & & & & \\
\hline Intestinal samples & 68 & & & & \\
\hline Feather 1 & 1 & & & & \\
\hline Feather 2 & 1 & & & & \\
\hline Drippings 2 (post-defeathering) & 1 & & & & \\
\hline Drippings 3 (pre-chilling) & 2 & & & & \\
\hline
\end{tabular}


and $A$. cryaerophilus, but not $A$. skirrowii, were detected in the intestinal content of 6 of the 30 hens from flock 2 . In flock 3 (hens), only 5 intestinal tracts were found positive by PCR. A. butzleri and A. cryaerophilus were isolated from 10 tracts (including two PCR- positive ones). From one broiler flock (flock 4) A. butzleri was detected by PCR and isolated from 1 of the 30 intestinal tracts. To reconfirm the presence of Arcobacter species in broiler intestines, carcasses and intestinal tracts were collected from another broiler
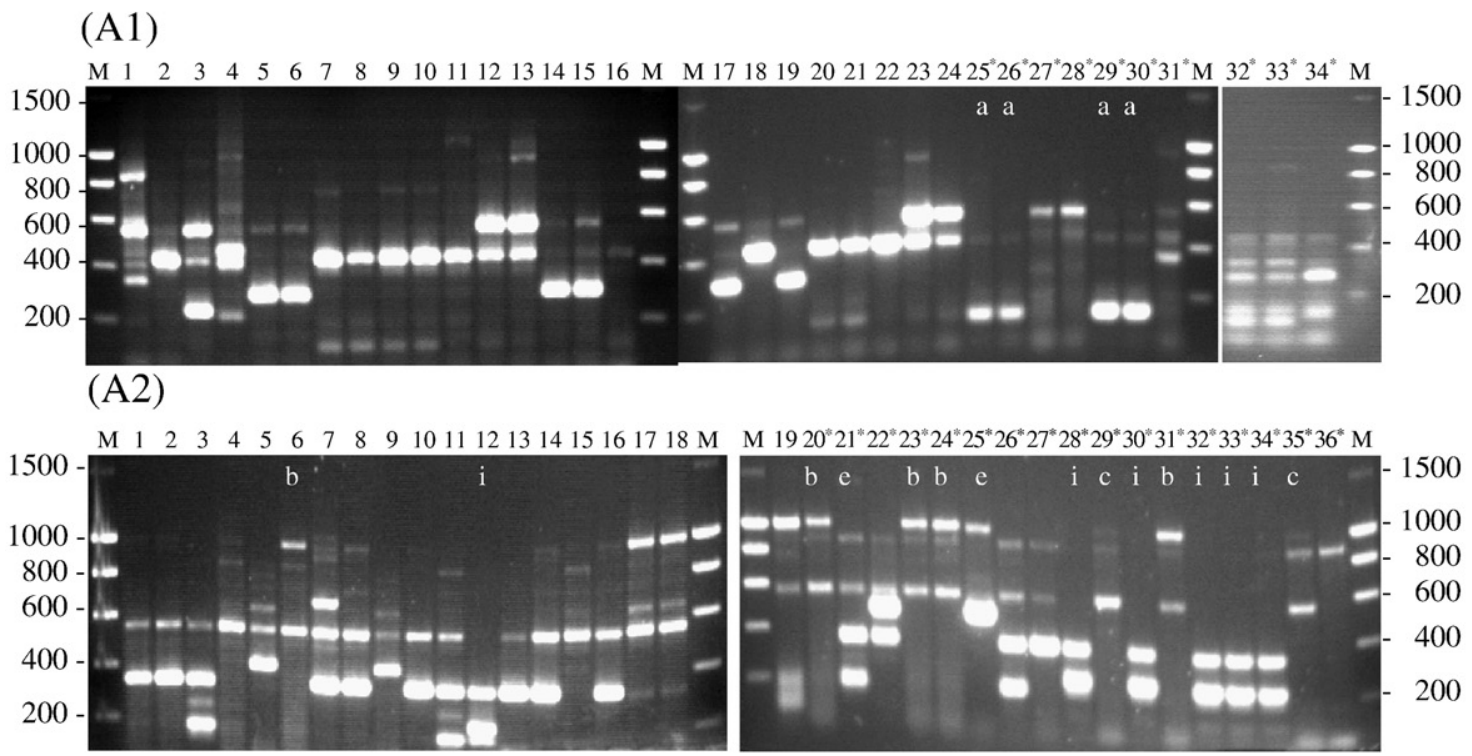

(B)

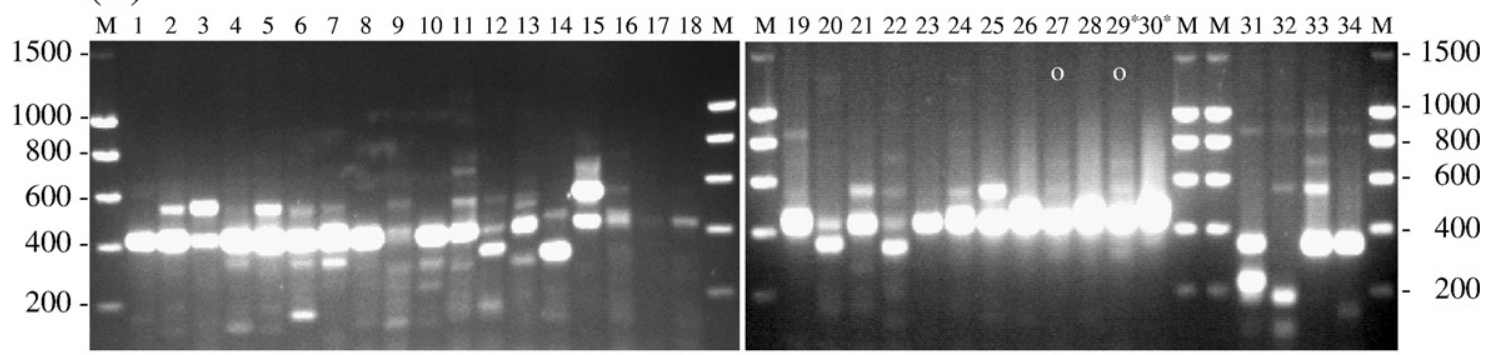

(C)

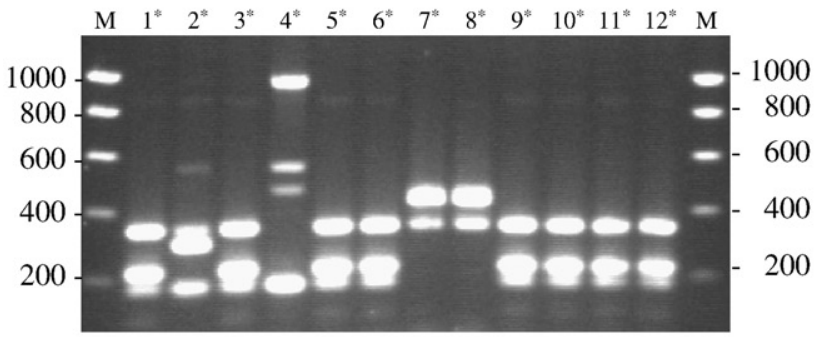

(D)

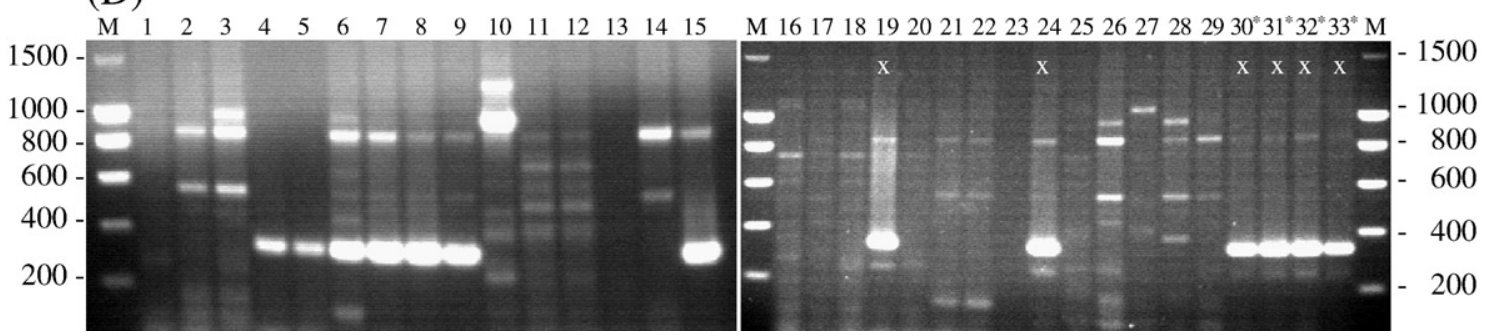

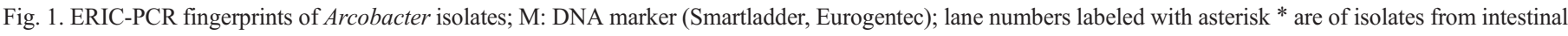

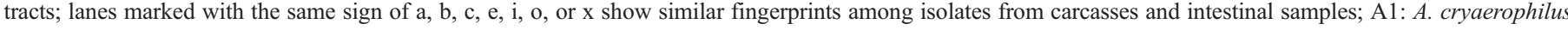

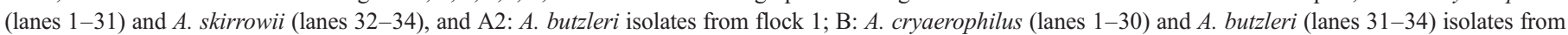
flock 2; C: A. butzleri isolates gut contents from flock 3; D: A. butzleri isolates from broilers. 
flock (flock 5) on another visit and the presence of Arcobacter spp. was detected only by PCR. Fifty one out of the 100 intestinal tracts were found positive.

At the broiler slaughterhouse, various water samples were taken during the 2 visits and examined for Arcobacter species. Arcobacter spp. were not detected by either PCR or isolation in all supply water samples. In contrast, the bacteria were detected by PCR in carcass-draining-off water samples from all sampling sites (Table 1). Unfortunately, due to the overgrowth by some swarming microorganisms Arcobacter species were only isolated from two carcass-draining-off samples taken after defeathering and identified as A. cryaerophilus.

\subsection{ERIC-PCR fingerprinting of Arcobacter isolates}

ERIC-PCR fingerprints of Arcobacter isolates from carcasses and intestinal content are shown in Fig. 1. In general, in each flock a genotypically diverse set of isolates were detected on the carcasses. Genetic heterology was also observed among isolates from the gut content of chickens from the same flock. In each flock several similar genotypes were detected on different carcasses and in different intestinal tracts but only one or two isolates from carcasses had similar patterns as the intestinal isolates. Furthermore, the fingerprint of the A. cryaerophilus isolate from faeces on the farm of flock 1 (lane 1, Fig. 1-A1) was different from that of all carcass and gut isolates from this flock. Similarly, the faecal A. skirrowii isolates from this farm (lanes 32 and 33, Fig. 1-A1) had a pattern different from that of the A. skirrowii isolate in a caecal sample (lane 34, Fig. 1-A1).

\subsection{Survival of Arcobacter species under scalding conditions}

Since Arcobacter species are mesophilic and unable to grow at $42{ }^{\circ} \mathrm{C}$ (Vandamme et al., 1991), the ability of five Arcobacter isolates to survive the scalding conditions was examined with

Table 3

Assay on survival of Arcobacter isolates at scalding conditions

\begin{tabular}{|c|c|c|c|c|}
\hline & \multicolumn{2}{|c|}{$\begin{array}{l}\log _{10} \text { CFUs per } \mathrm{ml} \\
\left(52^{\circ} \mathrm{C} / 3 \mathrm{~min}\right)\end{array}$} & \multicolumn{2}{|c|}{$\begin{array}{l}\log _{10} \text { CFUs per } \mathrm{ml} \\
\left(58^{\circ} \mathrm{C} / 3 \mathrm{~min}\right)\end{array}$} \\
\hline & Inoculum & Survival & Inoculum & Surviva \\
\hline \multirow{3}{*}{$\begin{array}{l}\text { A. skirrowii } 9 \mathrm{C} 1 \\
\text { (hen caecal isolate) }\end{array}$} & 6.6 & 4.1 & 6.4 & 2.7 \\
\hline & 5.4 & 1.6 & 5.4 & ND \\
\hline & 4.4 & ND & 4.4 & ND \\
\hline \multirow{3}{*}{$\begin{array}{l}\text { A. cryaerophilus } \mathrm{K} 21 \mathrm{a} \\
\text { (hen carcass isolate) }\end{array}$} & 6.1 & 3.1 & 6.1 & 2.8 \\
\hline & 5.1 & 4.4 & 5.1 & 2.1 \\
\hline & 4.6 & 2.0 & 4.1 & ND \\
\hline \multirow{3}{*}{$\begin{array}{l}\text { A. cryaerophilus } \mathrm{K} 141 \mathrm{~b} \\
\text { (hen carcass isolate) }\end{array}$} & 6.4 & 5.8 & 6.4 & 3.3 \\
\hline & 5.4 & 3.9 & 5.4 & 1.9 \\
\hline & 4.3 & 2.4 & 4.4 & ND \\
\hline \multirow{3}{*}{$\begin{array}{l}\text { A. butzleri } \mathrm{K} 21 \mathrm{c} \\
\text { (hen carcass isolate) }\end{array}$} & 6.5 & 5.6 & 6.6 & 3.9 \\
\hline & 5.6 & 4.2 & 5.6 & 2.8 \\
\hline & 4.6 & 1.9 & 4.6 & ND \\
\hline \multirow{3}{*}{$\begin{array}{l}\text { A. butzleri } \mathrm{K} 429 \mathrm{a} \\
\text { (broiler carcass isolate) }\end{array}$} & 6.1 & 4.3 & 6.8 & ND \\
\hline & 5.8 & 2.2 & 5.8 & ND \\
\hline & 4.8 & 1.8 & 4.8 & ND \\
\hline
\end{tabular}

ND: Not detected. different bacterial inocula $\left(10^{6}, 10^{5}, 10^{4} \mathrm{CFUs} / \mathrm{ml}\right)$. After exposure to $52^{\circ} \mathrm{C}$ for $3 \mathrm{~min}$, the bacterial numbers were reduced approximately $0.6-4.0 \log _{10} \mathrm{CFU} / \mathrm{ml}$ (Table 3). At $58{ }^{\circ} \mathrm{C}$, at least $3 \log _{10} \mathrm{CFUs} / \mathrm{ml}$ reduction was demonstrated. Heat resistance seemed strain-dependent.

\section{Discussion}

The present study was performed to determine the sources of introduction of Arcobacter spp. in slaughterhouses. Arcobacters could not be recovered from the supply water whereas almost all sampled carcasses and water draining off carcasses at different processing stages were positive. It seems impossible that the slaughterhouse supply water is the source of arcobacter contamination on carcasses. The results demonstrated the presence of Arcobacter spp. in the intestinal content of all sampled hen and broiler flocks albeit with different frequencies (Tables 1 and 2). Likewise, Arcobacter species were isolated from 1/15 intestinal tracts in a study by Atabay and Corry (1997) and from $1 / 10$ intestinal tracts for each of two flocks in a study by Van Driessche and Houf (2007). In Japan, arcobacters were isolated from $14.6 \%$ of cloacal swabs taken from 234 chickens on farms (Kabeya et al., 2003).

Furthermore, the ERIC-PCR results demonstrated that a few arcobacter genotypes in the intestines were similar to genotypes on carcasses of the same flock. This indicates that Arcobacter spp. can be introduced in a slaughterhouse by the gut contents of chickens. The finding of extreme genetic diversity of isolates on carcasses in the present study as well as in the literature (Houf et al., 2003; Son et al., 2006; Van Driessche and Houf, 2007) can be explained by cross-contamination among slaughtered chickens within one flock and from flocks of different farms. Spreading of Campylobacter spp. from previously slaughtered birds to subsequent flocks has been clearly demonstrated (Rivoal et al., 1999; Newell et al., 2001; Miwa et al., 2003). This cross-contamination can already start during transportation if already-contaminated crates are used. It can also occur during scalding, defeathering and evisceration through contaminated equipment, air and personnel (Berndtson et al., 1996; Ono and Yamamoto, 1999; FAO/WHO, 2002; Hansson et al., 2005; Posch et al., 2006; Allen et al., 2007). The results in the present study indicated that these transmission routes seem the same for arcobacters. Arcobacter spp. are found on equipment along the processing line and in processing water: water in the scalding tank, water outlets of the defeathering machine and washers (Houf et al., 2002b; Gude et al., 2005). The bacteria were also isolated from the transportation crates used by flocks from which no Arcobacter species were detected in their caecal contents (Houf et al., 2002b). In our study, the bacteria were present in water draining off carcasses just leaving the scalding tank (before entering the defeathering stage), after defeathering and before going to the chilling room. The survival test on some Arcobacter isolates at a scalding temperature of $52{ }^{\circ} \mathrm{C}$ in tap water for 3 min indicated that a proportion of the Arcobacters that contaminated the scalding water can survive these conditions and cause cross-contaminating within and between flocks in the scalding tank and in later processing stages. 
The recovery of Arcobacter species in live birds or intestinal contents depends on sampling size and place. In most studies in the literature only a small numbers of samples were taken (Atabay and Corry, 1997; Gude et al., 2005; Van Driessche and Houf, 2007). The sampling site also appears to be important. In the present study, Arcobacter spp. were detected more often in ileal samples than in caecal samples. For salmonellae, it has been demonstrated that different results can be obtained by samplings at different parts of the chicken intestines (Rasschaert et al., 2007). The survival of campylobacters in parts of the intestines is dependent on the ecology of that part of the intestines. It has been indicated that caeca and cloaca are the primary colonisation sites of Campylobacter spp. in chicken intestines (Beery et al., 1988; Amit-Romach et al., 2004). Arcobacter species being aerotolerant could favour the ileum instead of the more anaerobic caeca.

Finally, the prevalence of Arcobacter spp. could be underestimated due to difficulties in isolation of these bacteria. In particular, the intestinal flora harbours larger numbers of enteric bacteria and fungi and yeasts compared to carcasses. In the present study Arcobacter spp. could not be isolated without filtration, due to overgrowth of other enteric microorganisms. A. skirrowii was detected in some samples by m-PCR but could not be isolated. The co-existence of more than one species in a sample was shown at higher rates by m-PCR than by isolation. In general PCR gave better results for demonstration of the presence of Arcobacter species, which is in agreement with the experience of other research groups (Fera et al., 2004; Gonzalez et al., 2007). However, as shown in Table 1 the PCR method sometimes also failed to detect the bacteria in enrichment samples. Since these samples also yielded negative results for the PCR using eubacterial primers, the presence of inhibiting factors in the samples can be assumed.

The results from this present study clearly indicate that Arcobacter spp. are imported into slaughterhouses by the gut contents of chickens. Processing in the slaughterhouses seems to be responsible for the spread of Arcobacter species from the intestines to carcasses. The supply water does not seem to play a role in introducing arcobacters in a slaughterhouse. The observed large genetic diversity of Arcobacter spp. present on carcasses can be explained by cross-contamination between chickens of one flock and between chickens of different flocks.

\section{References}

Allen, V.M., Bull, S.A., Corry, J.E., Domingue, G., Jorgensen, F., Frost, J.A., Whyte, R., Gonzalez, A., Elviss, N., Humphrey, T.J., 2007. Campylobacter spp. contamination of chicken carcasses during processing in relation to flock colonisation. Int. J. Food Microbiol. 113, 54-61.

Amit-Romach, E., Sklan, D., Uni, Z., 2004. Microflora ecology of the chicken intestine using $16 \mathrm{~S}$ ribosomal DNA primers. Poult. Sci. 83, 1093-1098.

Atabay, H.I., Corry, J.E., 1997. The prevalence of campylobacters and arcobacters in broiler chickens. J. Appl. Microbiol. 83, 619-626.

Beery, J.T., Hugdahl, M.B., Doyle, M.P., 1988. Colonization of gastrointestinal tracts of chicks by Campylobacter jejuni. Appl. Environ. Microbiol. 54, 2365-2370.

Berndtson, E., Danielsson-Tham, M.L., Engvall, A., 1996. Campylobacter incidence on a chicken farm and the spread of Campylobacter during the slaughter process. Int. J. Food Microbiol. 32, 35-47.

de Boer, E., Tilburg, J.J., Woodward, D.L., Lior, H., Johnson, W.M., 1996. A selective medium for the isolation of Arcobacter from meats. Lett. Appl. Microbiol. 23, $64-66$.
Eifert, J.D., Castle, R.M., Pierson, F.W., Larsen, C.T., Hackney, C.R., 2003. Comparison of sampling techniques for detection of Arcobacter butzleri from chickens. Poult. Sci. 82, 1898-1902.

FAO/WHO, 2002. Risk assessment of Campylobacter spp. in broiler chicken and Vibrio spp. in seafood. Report of a join FAO/WHO Expert Consultation, 5-9 August 2002, Bangkok, Thailand (http://www.fao.org/docrep/008/ y8145e/y8145e00.htm).

Fera, M.T., Maugeri, T.L., Gugliandolo, C., Beninati, C., Giannone, M., La Camera, E., Carbone, M., 2004. Detection of Arcobacter spp. in the coastal environment of the Mediterranean sea. Appl. Environ. Microbiol. 70, $1271-1276$.

Gonzalez, A., Botella, S., Montes, R.M., Moreno, Y., Ferrus, M.A., 2007. Direct detection and identification of Arcobacter species by multiplex PCR in chicken and wastewater samples from Spain. J. Food Prot. 70, 341-347.

Gude, A., Hillman, T.J., Helps, C.R., Allen, V.M., Corry, J.E., 2005. Ecology of Arcobacter species in chicken rearing and processing. Lett. Appl. Microbiol. 41, $82-87$.

Hansson, I., Ederoth, M., Andersson, L., Vagsholm, I., Olsson Engvall, E., 2005. Transmission of Campylobacter spp. to chickens during transport to slaughter. J. Appl. Microbiol. 99, 1149-1157.

Harmon, K.M., Wesley, I.V., 1996. Identification of Arcobacter isolates by PCR. Lett. Appl. Microbiol. 23, 241-244.

Houf, K., De Zutter, L., Van Hoof, J., Vandamme, P., 2002a. Assessment of the genetic diversity among arcobacters isolated from poultry products by using two PCR-based typing methods. Appl. Environ. Microbiol. 68, 2172-2178.

Houf, K., De Zutter, L., Van Hoof, J., Vandamme, P., 2002b. Occurrence and distribution of Arcobacter species in poultry processing. J. Food Prot. 65, 1233-1239.

Houf, K., De Zutter, L., Verbeke, B., Van Hoof, J., Vandamme, P., 2003. Molecular characterization of Arcobacter isolates collected in a poultry slaughterhouse. J. Food Prot. 66, 364-369.

Houf, K., Tutenel, A., De Zutter, L., Van Hoof, J., Vandamme, P., 2000. Development of a multiplex PCR assay for the simultaneous detection and identification of Arcobacter butzleri, Arcobacter cryaerophilus and Arcobacter skirrowii. FEMS Microbiol. Lett. 193, 89-94.

Kabeya, H., Maruyama, S., Morita, Y., Kubo, M., Yamamoto, K., Arai, S., Izumi, T., Kobayashi, Y., Katsube, Y., Mikami, T., 2003. Distribution of Arcobacter species among livestock in Japan. Vet. Microbiol. 93, 153-158.

Kabeya, H., Maruyama, S., Morita, Y., Ohsuga, T., Ozawa, S., Kobayashi, Y., Abe, M., Katsube, Y., Mikami, T., 2004. Prevalence of Arcobacter species in retail meats and antimicrobial susceptibility of the isolates in Japan. Int. J. Food Microbiol. 90, 303-308.

Miwa, N., Takegahara, Y., Terai, K., Kato, H., Takeuchi, T., 2003. Campylobacter jejuni contamination on broiler carcasses of $C$. jejuni-negative flocks during processing in a Japanese slaughterhouse. Int. J. Food Microbiol. 84, 105-109.

Newell, D.G., Shreeve, J.E., Toszeghy, M., Domingue, G., Bull, S., Humphrey, T., Mead, G., 2001. Changes in the carriage of Campylobacter strains by poultry carcasses during processing in abattoirs. Appl. Environ. Microbiol. 67, $2636-2640$.

Ono, K., Yamamoto, K., 1999. Contamination of meat with Campylobacter jejuni in Saitama, Japan. Int. J. Food Microbiol. 47, 211-219.

Posch, J., Feierl, G., Wuest, G., Sixl, W., Schmidt, S., Haas, D., Reinthaler, F.F., Marth, E., 2006. Transmission of Campylobacter spp. in a poultry slaughterhouse and genetic characterisation of the isolates by pulsed-field gel electrophoresis. Br. Poult. Sci. 47, 286-293.

Rasschaert, G., Houf, K., Van Hende, J., De Zutter, L., 2007. Investigation of the concurrent colonization with Campylobacter and Salmonella in poultry flocks and assessment of the sampling site for status determination at slaughter. Vet. Microbiol. 123, 104-109.

Rivas, L., Fegan, N., Vanderlinde, P., 2004. Isolation and characterisation of Arcobacter butzleri from meat. Int. J. Food Microbiol. 91, 31-41.

Rivoal, K., Denis, M., Salvat, G., Colin, P., Ermel, G., 1999. Molecular characterization of the diversity of Campylobacter spp. isolates collected from a poultry slaughterhouse: analysis of cross-contamination. Lett. Appl. Microbiol. 29, 370-374.

Son, I., Englen, M.D., Berrang, M.E., Fedorka-Cray, P.J., Harrison, M.A., 2006. Genetic diversity of Arcobacter and Campylobacter on broiler carcasses during processing. J. Food Prot. 69, 1028-1033. 
Son, I., Englen, M.D., Berrang, M.E., Fedorka-Cray, P.J., Harrison, M.A., 2007. Prevalence of Arcobacter and Campylobacter on broiler carcasses during processing. Int. J. Food Microbiol. 113, 16-22.

Van Driessche, E., Houf, K., 2007. Discrepancy between the occurrence of Arcobacter in chickens and broiler carcass contamination. Poult. Sci. 86, 744-751.
Vandamme, P., De Ley, J., 1991. Proposal for a new family, Campylobacteraceae. Int. J. Syst. Bacteriol. 41, 451-455.

Vandamme, P., Falsen, E., Rossau, R., Hoste, B., Segers, P., Tytgat, R., De Ley, J., 1991. Revision of Campylobacter, Helicobacter, and Wolinella taxonomy: emendation of generic descriptions and proposal of Arcobacter gen. nov. Int. J. Syst. Bacteriol. 41, 88-103. 